\title{
The hydrothermal alteration of carbonatite in the Fen Complex, Norway: mineralogy, geochemistry, and implications for rare-earth element resource formation
}

\author{
C. Marien ${ }^{*}$, A. H. Dijkstra And C. Wilkins
}

School of Geography, Earth and Environmental Sciences, Plymouth University, Fitzroy Building, Drake Circus, Plymouth PL4 8AA, UK

[Received 3 March 2017; Accepted 5 September 2017; Associate Editor: Nigel Cook]

\section{ABSTRACT}

The Fen Complex in Norway consists of a $~ 583$ Ma composite carbonatite-ijolite-pyroxenite diatreme intrusion. Locally, high grades (up to $1.6 \mathrm{wt} . \%$ total $R E E$ ) of rare-earth elements $(R E E)$ are found in a hydrothermally altered, hematite-rich carbonatite known as rødbergite. The progressive transformation of primary igneous carbonatite to rødbergite was studied here using scanning electron microscopy and inductively coupled plasma-mass spectrometry trace-element analysis of 23 bulk samples taken along a key geological transect. A primary mineral assemblage of calcite, dolomite, apatite, pyrite, magnetite and columbite with accessory quartz, baryte, pyrochlore, fluorite and $R E E$ fluorocarbonates was found to have transformed progressively into a secondary assemblage of dolomite, Fe-dolomite, baryte, Ba-bearing phlogopite, hematite with accessory apatite, calcite, monazite-(Ce) and quartz. Textural evidence is presented for $R E E$ fluorocarbonates and apatite breaking down in igneous carbonatite, and monazite-(Ce) precipitating in rødbergite. The importance of micro-veins, interpreted as feeder fractures, containing secondary monazite and allanite, is highlighted. Textural evidence for included relics of primary apatite-rich carbonatite are also presented. These acted as a trap for monazite-(Ce) precipitation, a mechanism predicted by physical-chemical experiments. The transformation of carbonatite to rødbergite is accompanied by a 10fold increase in $R E E$ concentrations. The highest light $R E E$ ( $L R E E$ ) concentrations are found in transitional vein-rich rødbergite, whereas the highest heavy REE (HREE) and Th concentrations are found within the rødbergites, suggesting partial decoupling of $L R E E$ and HREE due to the lower stability of HREE complexes in the aqueous hydrothermal fluid. The hydrothermal fluid involved in the formation of rødbergite was oxidizing and had probably interacted with country-rock gneisses. An ore deposit model for the $R E E$-rich rødbergites is presented here which will better inform exploration strategies in the complex, and has implications for carbonatite-hosted $R E E$ resources around the world.

KeYwords: rødbergite, ICP-MS, SEM, carbonatite-ijolite-pyroxenite complex, REE mobility, monazite-(Ce), apatite, thorium.

\section{Introduction}

THE Fen Complex in southeastern Norway (Fig. 1) is one of the world's classic carbonatite complexes; it was here that the igneous nature of carbonatite

*E-mail: christian.marien@gmx.de https://doi.org/10.1180/minmag.2017.081.070 was first recognized (Brøgger, 1921) and significant advances in the understanding of the petrology

This paper is part of a special open access issue in the Mineralogical Magazine entitled 'Critical-metal mineralogy and ore genesis'.

(C) The Mineralogical Society 2018. This is an Open Access article, distributed under the terms of the Creative Commons Attribution licence (http://creativecommons.org/licenses/by/4.0/), which permits unrestricted re-use, distribution, and reproduction in any medium, provided the original work is properly cited. 


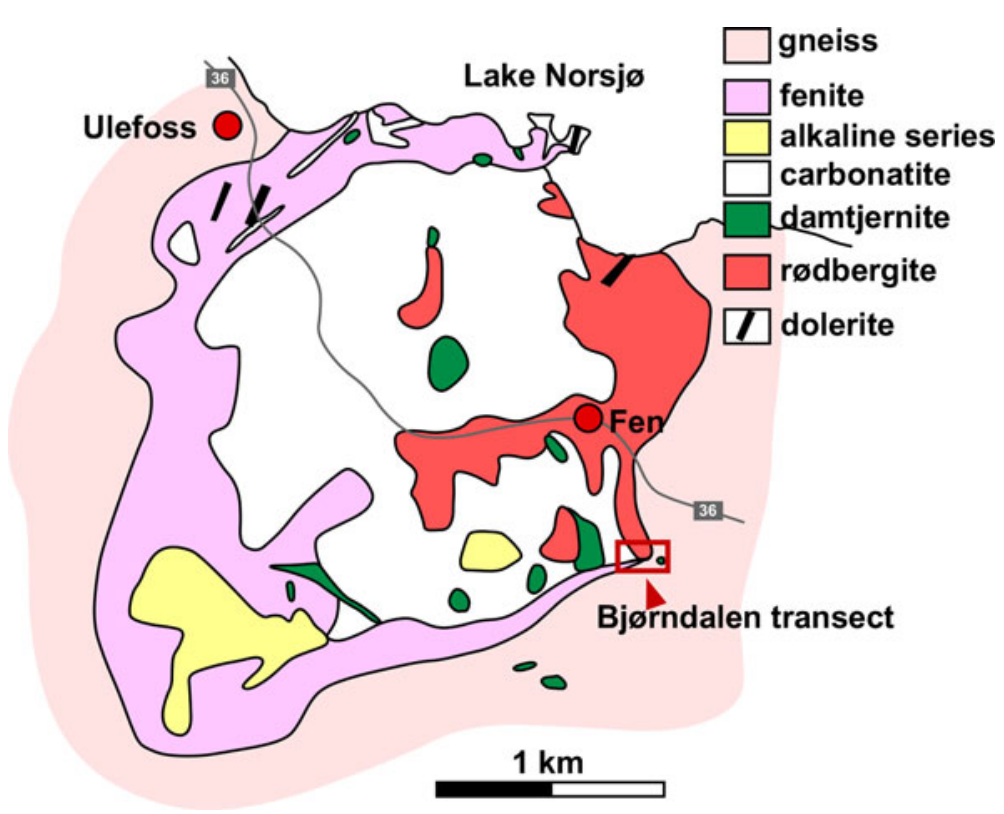

FIG. 1. Simplified geological map of the Fen Complex showing the main rock types and location of the sampling site (Bjørndalen transect) (after Sæther, 1957).

of carbonatites (Brøgger, 1921; Sæther, 1957; Ramberg, 1973; Griffin and Taylor, 1975; Mitchell and Brunfelt, 1975) and their REE contents (Andersen, 1984) were based on studies in the Fen Complex. The intrusion age of the Fen Complex is latest Neoproterozoic $\left(583 \pm 15 \mathrm{Ma}\right.$ by ${ }^{40} \mathrm{Ar} /{ }^{39} \mathrm{Ar}$ on phlogopite from a co-genetic ultramafic lamprophyre; (Meert et al., 1998)). The plug-shaped Fen complex has an exposed surface area of $\sim 6 \mathrm{~km}^{2}$ (Fig. 1) and consists of a carbonatite-ijolite-pyroxenite composite intrusion (Bergstøl and Svinndal, 1960).

Carbonatites, igneous rocks with $>50 \%$ carbonate minerals, show economic potential as they have the highest average concentration of REE of all magmatic rocks and considerable amounts of $\mathrm{Nb}$ and $\mathrm{P}$ (Cullers and Graf, 1984). REE are a resource of critical and strategic importance for present and future technology (European Commission, 2014). Carbonatite complexes such as Bayan Obo (China), Araxá and Catalão (Brazil) and Phalaborwa (South Africa) are the main sources for light rare-earth elements (LREE) and $\mathrm{Nb}$, and also contain significant reserves of $\mathrm{Cu}, \mathrm{Ti}$, baryte, fluorite, vermiculite, Sr, V, Th, U and P (Mariano, 1989; Groves and Vielreicher, 2001; Cordeiro et al., 2011; Smith et al., 2015). The carbonatites of the Fen Complex contain a range of REE minerals, e.g. REE fluorocarbonates, monazite-(Ce), allanite, as well as REE-bearing minerals such as apatite (Andersen, 1986). The highest REE concentrations (up to 15,000 ppm total $R E E$ ) in the Fen Complex were detected in rødbergite (Mitchell and Brunfelt, 1975). Rødbergite ('red rock' in Norwegian) is usually defined as a calcite-dolomite carbonatite stained red by disseminated fine crystals of hematite (Andersen, 1984).

According to Andersen (1984, 1986, 1987a, 1987b) rødbergite formed by the replacement and alteration of ferrocarbonatites along zones of intense fracturing by hydrothermal fluids. The decrease in $\delta^{18} \mathrm{O}$ and the increase in $\delta^{13} \mathrm{C}$ and ${ }^{87} \mathrm{Sr} /{ }^{86} \mathrm{Sr}$ values indicate the influx of an oxidizing groundwater derived from a reservoir rich in radiogenic $\mathrm{Sr}$ (Andersen, 1984, 1986, 1987a, 1987b). The oxygen fugacity during the alteration increased subsequently and caused the oxidation of pyrite and the release of $\mathrm{H}^{+}$during the breakdown of pyrite supporting the dissolution of carbonate minerals. Andersen (1984, 1986, 1987a, 1987b) inferred a volume reduction of as much as $70 \mathrm{vol} . \%$ of rock for the most altered parts, which led to a residual enrichment of insoluble phases e.g. hematite and REE minerals. While REE minerals are considered to have been stable during the alteration, $L R E E$ were leached preferentially by the F-rich fluids; MREE, Y and $\mathrm{Th}$ are the least soluble elements in the 
ferrocarbonatite and were strongly enriched in the solid residue (rødbergite) in this model.

Although Andersen's model for the formation of rødbergite is widely accepted in the scientific community, and has, for instance, recently been applied to the formation of similar rocks in the Gifford Creek Ferrocarbonatite Complex in Western Australia (Pirajno et al., 2014), there are still open questions regarding the REE distribution and $R E E$ concentration mechanism within the Fen complex. REE exploration activities conducted by Fen Minerals AS and REE Minerals AS in recent years have produced new geochemical data and reevaluated older data sets. These recent activities confirm rødbergite as the rock type with the highest average concentration of total REE (TREE) within the Fen Complex (21st North, 2014; Marien et al., 2016). However, chemical data acquired by the Norwegian Geological Survey (1967-1970) shows a significant variation in $R E E$ concentration and variation in $L R E E$ to $H R E E$ ratios for rødbergite (21st North, 2014). REE are generally divided into two subgroups: the LREE (La to $\mathrm{Sm}$ ) and HREE (Gd to Lu including Y) (Henderson, 1996). The present study reports new bulk-rock REE concentrations and mineralogical observations, and focuses on the detail of REE distribution and the $R E E$ concentration mechanism in the rødbergite. In order to learn more about the formation process of rødbergite, a coherent alteration transect from primary carbonatite to rødbergite has been sampled in detail for the first time and interpreted in terms of mineralogy, texture and geochemistry.

\section{Methods}

Based on fieldwork, several well exposed transitions from igneous carbonatite to rødbergite have been identified in the Fen Complex. In the present contribution, the focus is on the Bjørndalen transect in the eastern part of the Fen Complex (Fig. 1, UTM $32 \mathrm{~V} 5175416569595)$, as it provides an excellent insight into the transformation of carbonatite to rødbergite over a relatively short distance, which made it suitable for dense sampling. A series of 23 rock samples were taken along the $\sim 30 \mathrm{~m}$ long Bjørndalen transect in order to represent the different stages of alteration from primary igneous carbonatite to rødbergite.

Mineral identification and textural analysis of samples was carried out by means of scanning electron microscopy (SEM) at the Plymouth Electron Microscopy Centre using a JEOL 7001 Field Emission Gun SEM equipped with a fast
Oxford Instruments EDS system for point analysis and for acquisition of large-area mosaics of highresolution elemental maps (typically of several hundreds of fields), using an acceleration voltage of $15-20 \mathrm{kV}$ and a working distance of $10 \mathrm{~mm}$. Acquisition and data processing was carried out using Oxford Instruments' Aztec software.

Rare-earth element concentrations, as well as those of selected other elements $(\mathrm{Nb}, \mathrm{Th}, \mathrm{U}, \mathrm{Ta}$, $\mathrm{Zr}$, Hf), were measured in solutions using the VG PQA3 Inductively Coupled Plasma-Mass Spectrometer (ICP-MS) in the trace-metal laboratory at Plymouth University. Initial digestions of rock powder by conventional multi-acid $\left(\mathrm{HNO}_{3}\right.$, $\mathrm{HCl}, \mathrm{HF}$ ) methods in Teflon vials at $220^{\circ} \mathrm{C}$ left insoluble material in the vast majority of the samples. Therefore, solutions were obtained by sodium peroxide sintering digestion according to Bokhari and Meisel (2016): $100 \mathrm{mg}$ of sample was mixed with $\sim 600 \mathrm{mg}$ of $\mathrm{Na}_{2} \mathrm{O}_{2}$ (finely ground Merck analytical-grade granular sodium peroxide) in high-purity nickel crucibles and heated for $60 \mathrm{~min}$ at $480^{\circ} \mathrm{C}$ in a conventional muffle oven. The resulting sinter cake was dissolved in $90^{\circ} \mathrm{C}$ ultrapure water (Elga Purelab flex, $>18.2 \mathrm{M} \Omega \mathrm{cm}$ ), centrifuged, and the clear solution decanted. The water-insoluble residue was dissolved in $3 \mathrm{~mL}$ of concentrated $\mathrm{HNO}_{3}$ (analytical grade), and $1-5 \mathrm{~mL}$ of concentrated $\mathrm{HCl}$ (trace-element analysis grade) was added to dissolve any remaining iron oxides and hydroxides if present. After this step, no residue was left in any of the samples. The clear solutions were added together and made up to $100 \mathrm{~mL}$ in volumetric flasks using ultrapure water; effective dilutions were $\sim 1000$ times. Total procedural blanks, acid blanks and digestions of REE-1 Certified Reference Material (Strange Lake REE$\mathrm{Nb}$ ore, Natural Resources Canada) were part of the analytical programme. Internal In-Ir standard solutions were added to each sample before ICP-MS analysis to correct for instrumental drift, and concentrations were calibrated with matrixmatched standard solutions spanning the full range of expected concentrations for each element $(0.1-$ $5000 \mathrm{ppb}$ ). Total procedural blanks were $0.5 \mathrm{ppb}$ for Ce but $<0.2 \mathrm{ppb}$ for the other REE, typically 0.025 $0.002 \mathrm{ppb}$ for $\mathrm{Eu}-\mathrm{Lu}$. The relative precision and error (with respect to certified values) of the $R E E$, $\mathrm{Nb}, \mathrm{Ta}, \mathrm{Th}$ and $\mathrm{U}$ concentrations, estimated by repeated analysis of the REE-1 CRM, were typically $<4 \%$ and $<15 \%$, respectively. An empirical relation was used to correct for the interferences of $\mathrm{CeO}$ and $\mathrm{PrO}$ on ${ }^{157} \mathrm{Gd}$ and of $\mathrm{NdO}$ on ${ }^{159} \mathrm{~Tb}$ and on ${ }^{163} \mathrm{Dy}$. These interferences were constrained by 
TABLE 1. Trace-element concentrations (ppm) West to East along the transect.

\begin{tabular}{|c|c|c|c|c|c|c|c|c|c|c|c|c|c|c|c|c|c|c|c|c|c|c|c|c|c|}
\hline & \multicolumn{6}{|c|}{ Carbonatite } & \multicolumn{4}{|c|}{ Transitional carbonatite W } & \multicolumn{8}{|c|}{ Rødbergite } & \multicolumn{5}{|c|}{ Transitional Rødbergite E } & \multicolumn{2}{|c|}{ Rødbergite } \\
\hline & $\begin{array}{l}15- \\
82\end{array}$ & $\begin{array}{l}15- \\
83\end{array}$ & $\begin{array}{l}15- \\
84\end{array}$ & $\begin{array}{l}16- \\
21\end{array}$ & $\begin{array}{l}15- \\
85\end{array}$ & $\begin{array}{l}16- \\
18\end{array}$ & $\begin{array}{l}16- \\
20\end{array}$ & $\begin{array}{l}16- \\
20 / 2\end{array}$ & $\begin{array}{l}16- \\
19\end{array}$ & $\begin{array}{l}16- \\
17\end{array}$ & $\begin{array}{l}15- \\
86\end{array}$ & $\begin{array}{l}16- \\
104\end{array}$ & $\begin{array}{l}15- \\
88\end{array}$ & $\begin{array}{l}15- \\
88 / 2\end{array}$ & $\begin{array}{l}16- \\
23\end{array}$ & $\begin{array}{l}16- \\
22\end{array}$ & $\begin{array}{l}15- \\
89\end{array}$ & $\begin{array}{l}15- \\
90\end{array}$ & $\begin{array}{l}15- \\
91\end{array}$ & $\begin{array}{l}15- \\
92\end{array}$ & $\begin{array}{l}16- \\
110\end{array}$ & $\begin{array}{l}15- \\
93\end{array}$ & $\begin{array}{l}16- \\
111\end{array}$ & $\begin{array}{l}16- \\
112\end{array}$ & $\begin{array}{l}15- \\
94\end{array}$ \\
\hline & 6 & 2.9 & 50.6 & 7.1 & .2 & 0 & 133 & 28.9 & 47.2 & 51.8 & 2 & 96.3 & 270 & 232 & 292 & 214 & 110 & 80.6 & 126 & 101 & 108 & 191 & 319 & 144 & 288 \\
\hline $\mathrm{Zr}$ & & 898.7 & 71.2 & 34.4 & 52.9 & 37.0 & 66.2 & 76.5 & 52.5 & 58.6 & 588.3 & 96.4 & 252.7 & 338.7 & 167.1 & 148.5 & 153.9 & 214.9 & 229.6 & 234.8 & 8135.9 & 381.8 & 8 294.3 & 208.5 & 737.2 \\
\hline IO & & 989 & 220 & 355 & 84.4 & 100 & 47.3 & 39.7 & $<\mathrm{dl}$ & $<\mathrm{dl}$ & 166 & 331 & 167 & 1876 & 522 & 696 & 135 & 510 & 156 & 113 & 235 & 108 & 110 & & 1020 \\
\hline I & 313 & 297 & 136 & 284 & 120 & 353 & & 130 & 109 & 149 & 44 & 29 & & 4 & 108 & 1468 & 1326 & 2368 & 3344 & 2164 & 2348 & 3694 & 3712 & 2212 & 2705 \\
\hline e & & 677 & 355 & 431 & 426 & 733 & & 417 & 406 & 367 & 87 & 45 & 1308 & 1234 & 336 & 2828 & 2678 & 4170 & 6117 & 4056 & 2715 & 6698 & & 4033 & 5212 \\
\hline $\operatorname{Pr}$ & 6 & 58.9 & 33.8 & 51.0 & 40.7 & 68.4 & 41 & 40 & 36 & 39 & 82 & 58 & 179 & 16 & 39 & 316 & 295 & 440 & 651 & 435 & 474 & 706 & 732 & 446 & 50 \\
\hline Id & & 220 & 131 & 186 & 148 & & 160 & 155 & 130 & 134 & 323 & 229 & 676 & 60 & 189 & 1011 & 886 & 1307 & 2270 & 1298 & 1308 & 2414 & 2011 & 1275 & 1876 \\
\hline $\mathrm{Sm}$ & 35.0 & 38.1 & 27.6 & 27.6 & 22.2 & 38.3 & 32.0 & 31.1 & 19.7 & 20.1 & 69.3 & 42.1 & 155.5 & 137.3 & 61.5 & 125.8 & 111.4 & 131.2 & 204.6 & 131.9 & 154.8 & 211.2 & 260.0 & 144.2 & 187.2 \\
\hline $\mathrm{Eu}$ & 10.8 & 11.4 & 8.39 & 9.20 & 6.86 & 13.2 & 12.8 & 12.4 & 6.35 & 6.43 & 27.8 & 14.5 & 46.4 & 41.2 & 24.4 & 29.2 & 26.4 & 27.7 & 45.0 & 30.0 & 35.6 & 45.6 & 47.9 & 32.0 & 46.7 \\
\hline Gd & 27.1 & 27.8 & 18.9 & 21.5 & 18.3 & 30.0 & 32.3 & 31.8 & 16.2 & 16.2 & 63.4 & 34.4 & 99.3 & 87. & 59.0 & 67.2 & 52.9 & 57.8 & 88.8 & 58.2 & 61.5 & 93.6 & 94.7 & 70.1 & 107.0 \\
\hline & 352 & 3.72 & 263 & 278 & 242 & & 537 & 526 & 2.27 & 2.24 & 0 & 4.6 & & & 9 & & 5 & & 75 & 55 & & 87 & 12.5 & & \\
\hline Dy & 17.4 & 19.4 & 14.5 & 14.5 & 12.9 & 21.8 & 32.8 & 32.1 & 12.6 & 12.3 & 55.5 & 24.5 & 67. & 59. & 59.4 & 42.9 & 26.8 & 19.4 & 30.3 & 24.0 & 27.1 & 41.3 & 63.1 & 38.9 & 78 \\
\hline [o & & 336 & 50 & & 237 & & & & & & & 45 & & & & 88 & & & & & & 70 & & & \\
\hline Er & 7.14 & 8.71 & 7.11 & 6.78 & 6.51 & 10.2 & 15.3 & 15.1 & 6.66 & 6.50 & 26.7 & 12.5 & 37.9 & 33.6 & 36.3 & 26.8 & 14.2 & 11.3 & 16.1 & 13.5 & 14.3 & 22.7 & 27.5 & 19.5 & 44.3 \\
\hline $\mathrm{Tm}$ & 0.855 & 1.11 & 0.988 & 0.911 & 0.881 & 1.28 & & & 0.927 & & & 1.7 & & & & & 2.0 & 1.6 & & & & 30 & & & \\
\hline $\mathrm{Yb}$ & 5.34 & 7.17 & 7.00 & 6.07 & 5.87 & 8.03 & 11.1 & 10 & 6.41 & 5.93 & 20.7 & 11.5 & 35.9 & 32.0 & 32.7 & 25.3 & 13.4 & 11.7 & 15.7 & 13.3 & 13.9 & 19.8 & 20.9 & 17.6 & 42.9 \\
\hline u & 0.732 & 1.01 & 1.04 & 0.933 & 0.873 & 1.1 & 1.5 & 1. & 0.9 & 0.8 & 2 & 1. & 51 & 4 & 4.4 & 3.6 & 20 & 18 & 23 & 2.0 & & 28 & & & \\
\hline $\mathrm{Hf}$ & 1.70 & 5.20 & 1.39 & 1.24 & 0.845 & 0.763 & 1.30 & 1. & 0.515 & 0.881 & 4.8 & 1.4 & 3 & 4 & 3. & 2. & 3 & 2 & 3.2 & 3.6 & 2.4 & 4.4 & 4.2 & 5.1 & 7 \\
\hline $\mathrm{Ta}$ & 11.9 & 32.3 & 1.95 & 91.0 & 30.3 & 6.70 & 2.06 & 2.0 & 5.26 & $<\mathrm{d}$ & 29.6 & 74.5 & $<c$ & 5. & 0. & 4.0 & 4 & 2. & $<\mathrm{dl}$ & $<\mathrm{dl}$ & 2.1 & $<\mathrm{dl}$ & 0.3 & & \\
\hline Th & 117.6 & 219.7 & 66.7 & 35.1 & 34.3 & 66.1 & 192.6 & 190.2 & 53.1 & 25.2 & 284.5 & 136.1 & 773.1 & 781.1 & 376.7 & 919.8 & 986.8 & 404.7 & 752.2 & 626.9 & 366.5 & 494.0 & 578.4 & 751.8 & 928.5 \\
\hline & 20.6 & 5.76 & 2.04 & 70.1 & 41.2 & 73.4 & 15.9 & 15.4 & 32.4 & 7.20 & 45.3 & 20.4 & 14.2 & 12.9 & 22.0 & 11.7 & 6.4 & 6.0 & 11.9 & 13.6 & 13.1 & 15.6 & 9.4 & & 21.8 \\
\hline $\mathrm{La} / \mathrm{Yb}$ & 59 & 41 & 19 & 47 & 20 & 44 & 10 & 12 & 17 & 25 & 21 & 25 & 14 & 14 & 3 & 58 & 99 & 202 & 213 & 163 & 169 & 186 & 178 & 126 & 63 \\
\hline
\end{tabular}

$<\mathrm{dl}$ : below detection limit for the method (Three times the standard deviation of the total procedural blank). 
measurements of multiple single-element ( $\mathrm{La}, \mathrm{Ce}$, $\mathrm{Pr}, \mathrm{Nd}$ ) standard solutions spanning the full range of expected concentrations. The trace-element concentrations for the samples from the Bjørndalen transect are presented in Table 1.

\section{Mineralogy and petrology of the samples}

Based on the degree of rødbergitic alteration, the samples were divided into three major rock types: carbonatite, transitional rødbergite and rødbergite. General signs of rødbergitization were a change in colour from whitish carbonatite to reddish rødbergite, grain-size reduction and the occurrence of veins.

\section{Carbonatite}

The rock type 'carbonatite' represents the unaltered and weakly altered calcite-dolomite carbonatite with a grey to whitish colour and a grain size of $\sim 2 \mathrm{~mm}$. The calcite-dolomite carbonatite consists of primary calcite, dolomite, apatite, pyrite, magnetite and columbite with accessory quartz, baryte, pyrochlore, fluorite and REE fluorocarbonates (e.g. synchysite-(Ce) and parisite-(Ce); Fig. 2a-c). Apatite occurs as hypidiomorphic lozenge-shaped crystals, or aggregates with a preferred orientation producing slightly bluish layers (Fig. 2a,b). The carbonate minerals have a uniform, $\sim 2 \mathrm{~mm}$ grain size in hand specimen but reveal in the BSE image a fine irregular intergrowth of calcite and dolomite. Pyrite is present as euhedral cubes $(0.5 \mathrm{~mm})$ or larger xenomorphic aggregates together with fluorite and REE fluorocarbonates (Fig. 2c), where columbite forms equidimensional crystals $(\sim 0.5 \mathrm{~mm})$. REE fluorocarbonates are the main mineral host for $R E E$ in carbonatite and can be found as small $(5-20 \mu \mathrm{m})$ idiomorphic to hypidiomorphic crystals distributed homogenously as inclusions in calcite, dolomite and apatite, as well as in the form of larger grains $(20-50 \mu \mathrm{m})$ in pyritefluorite aggregates (Fig. 2c). The small crystals of $R E E$ fluorocarbonates can contain Th (up to 8 wt.\%). Some carbonatite samples show no evidence of alteration whereas other samples show incipient features of alteration such as the change from the primary whitish grey colouration to beige and earthy colours. The change in colour is caused by $\mathrm{Fe}$ oxides which preferentially invade along fractures and grain boundaries. The matrix in the vicinity of these Fe-oxide veins is dominated by a halo of fine-grained calcite. The carbonate minerals in the matrix display a speckled appearance in the BSE image caused by fine disseminated
Fe oxides $(<5 \mu \mathrm{m})$. The breakdown of pyrite is also a sign of incipient alteration with hematite replacing pyrite aggregates along grain boundaries forming a mosaic texture. In areas of alteration, REE fluorocarbonates are found exclusively enclosed by pyrite and the boundaries of the REE fluorocarbonates are irregular and crosscutting, indicating replacements by hematite (Fig. $2 d$ ).

\section{Transitional rødbergite}

Transitional rødbergite is a massive calcite-dolomite carbonatite with clear signs of alteration to rødbergite. Transitional rødbergite shows a mix of beige, yellow and greyish coloured irregularly shaped patches where calcite and dolomite are again the principal minerals with accessory baryte, quartz, Ba-bearing phlogopite, apatite, pyrite and monazite-(Ce) (Table 2). Calcite and dolomite have a grain size of $<200 \mu \mathrm{m}$ and show a fine, irregular intergrowth. Baryte is distributed evenly in the samples and forms xenomorphic crystals $(50 \mu \mathrm{m}$ to $1 \mathrm{~mm})$. Ba-bearing phlogopite, however, is concentrated in veins and in the matrix between veins. Transitional rødbergite from the eastern part of the Bjørndalen transect has a high vein density of up to two veins per $\mathrm{cm}^{2}$ (Fig. 3) compared to the unveined transitional rødbergite from the western Bjørndalen transect. REE fluorocarbonates occur as small homogenously distributed patches in the matrix of transitional rødbergite, but a large proportion of the $R E E$ is hosted in distinct micro-veins described below.

\section{Veins in transitional rødbergite}

Three different micro-vein sets can be distinguished in the eastern transitional rødbergite (Fig. 3). They are numbered on the basis of the observed crosscutting relations in the studied transect.

Hematite veins (Vein Set I) are thin $(10 \mu \mathrm{m})$ straight veins of hematite and clay minerals.

Monazite veins (Vein Set II) consist of Babearing phlogopite, baryte \pm monazite-(Ce), chlorite and hematite. Monazite-(Ce) $(100 \mu \mathrm{m} \times 30 \mu \mathrm{m})$ is enclosed by Ba-bearing phlogopite and found in intergrowth with hematite. In the vicinity of vein set II are irregular patches of monazite-(Ce) within the matrix. Set II veins are the most common veins and are parallel to each other but occasionally branch and display an irregular shape. Pyrite is found as idiomorphic cubes in the vicinity of or in contact with set II veins. Veins partially of monazite engulf older patches of quartz-baryte aggregates.

Allanite veins (Vein Set III) consist of calcite with minor amounts of baryte, dolomite, coarse-grained allanite $(0.3 \mathrm{~mm} \times 2 \mathrm{~mm})$ and rarely coarse-grained 

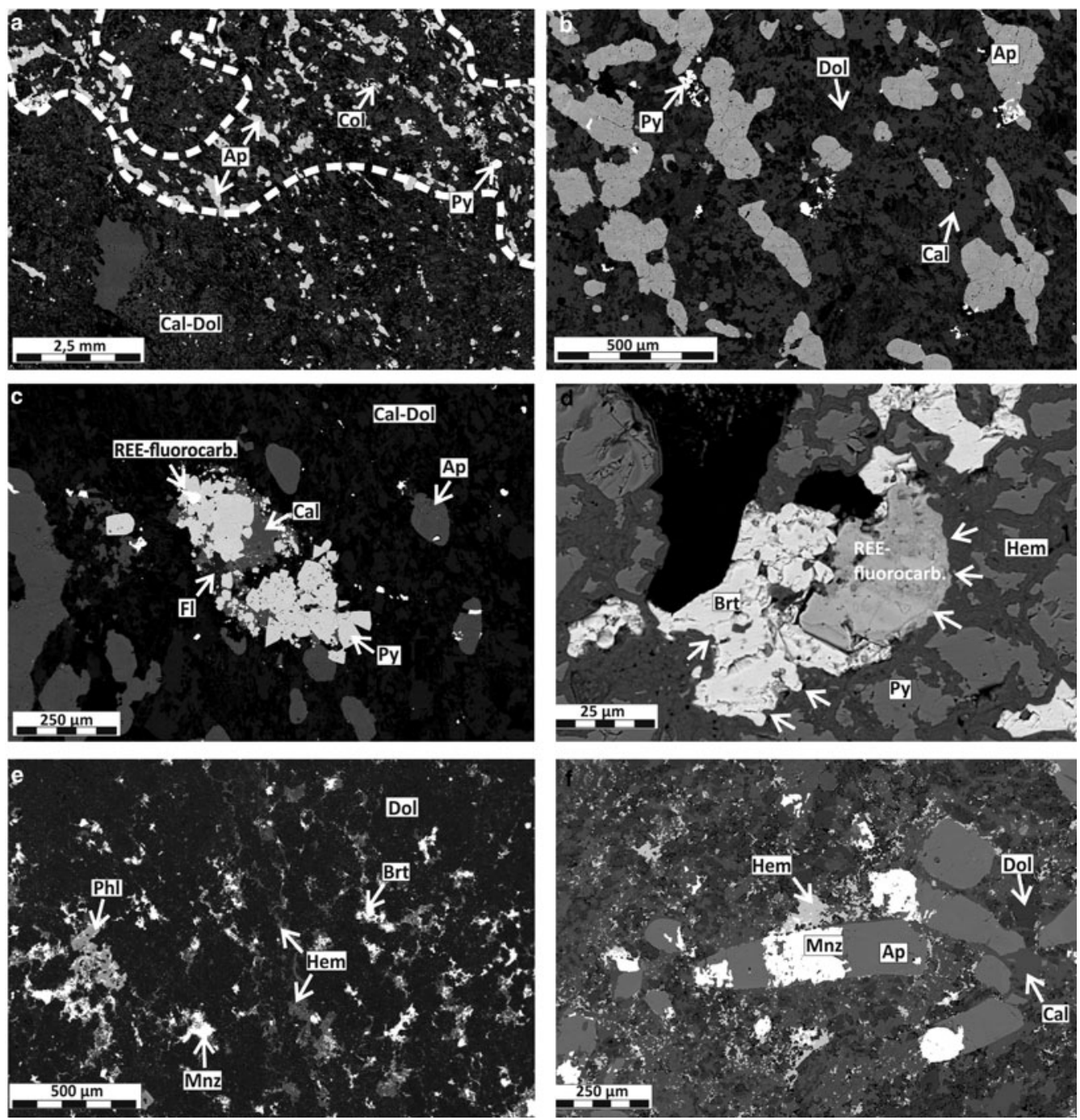

FIG. 2. BSE-SEM images showing the mineralogical and textural changes as a result of rødbergitization in samples from the Bjørndalen transect of the Fen Complex. (a) Apatite-rich carbonatite domains in carbonatite in sample 15-82-FE. (b) Close-up of the texture of a primary carbonatite (sample 15-82-FE) with apatite showing a preferred orientation. The matrix is comprised of an intergrowth of calcite (brighter grey) and dolomite (darker grey). (c) REE fluorocarbonates associated with fluorite and pyrite in primary carbonatite (sample 15-82-FE). (d) Primary pyrite replaced by veins of secondary hematite. $R E E$ fluorocarbonates and baryte inclusions at the centre of the altered pyrite are partly replaced by hematite (white arrows). Altered part of sample 15-82-FE. (e) Texture of rødbergite matrix showing fine-grained dolomite with a fine dense network of hematite, baryte and monazite-(Ce) replacing dolomite along grain boundaries (sample 15-89-FE). (f) Texture of a rødbergite matrix similar to (d) showing dolomite-calcite matrix with a fine dense network of hematite along grain boundaries. Monazite-(Ce) is partly replacing apatite (sample 15-88-FE). Mineral abbreviations used: Ap - apatite, Cal - calcite, Phl - phlogopite, Brt - baryte, Col - columbite, Dol - dolomite, Fl fluorite, Hem - hematite, Py - pyrite, Mnz - monazite-(Ce). 
TABLE 2. Summary of the essential and accessory minerals observed in carbonatite, transitional rødbergite, and rødbergite along the Bjørndalen transect.

\begin{tabular}{|c|c|c|}
\hline Carbonite & $\begin{array}{l}\text { Transitional } \\
\text { rødbergite }\end{array}$ & Rødbergite \\
\hline \multicolumn{3}{|l|}{ Main minerals } \\
\hline Calcite & Calcite & Dolomite \\
\hline Dolomite & Dolomite & Fe dolomite \\
\hline Apatite & & Baryte \\
\hline Pyrite & & Hematite \\
\hline Columbite & & $\begin{array}{c}\text { Ba-bearing } \\
\text { biotite }\end{array}$ \\
\hline \multicolumn{3}{|c|}{ Accessory minerals } \\
\hline Quartz & Baryte & Calcite \\
\hline Baryte & $\begin{array}{c}\text { Ba-bearing } \\
\text { biotite }\end{array}$ & Apatite \\
\hline Pyrochlore & Apatite & Quartz \\
\hline Fluorite & Monazite-(Ce) & Monazite-(Ce) \\
\hline$R E E$ fluoro- & Quartz & \\
\hline
\end{tabular}

synchisite-(Ce). The allanite veins are significantly thicker $(300 \mu \mathrm{m})$ than both set I and II veins.

\section{Rødbergite}

The rock type 'rødbergite' is intensely altered massive carbonatite with a fine crystalline carbonate matrix coloured in different shades of red. Porosities, determined from large-area scanning electron microscopy image mosaics, are $<2 \%$. Rødbergites consist of varying proportions of dolomite, Fedolomite, baryte, Ba-bearing phlogopite, hematite with accessory apatite, calcite, monazite-(Ce), quartz and $\mathrm{Ba}$-bearing feldspar. The matrix consists of idiomorphic to xenomorphic dolomite surrounded by a network of calcite grains with small hematite inclusions (Fig. 2e). While some parts of the matrix display a fine intergrowth of calcite and dolomite, other parts display a coarser crystal size and show evidence for the replacement of dolomite by calcite. Hematite can be found in veins, along crystal boundaries and as inclusions in carbonate minerals. Rødbergite also contains set II monazite veins that

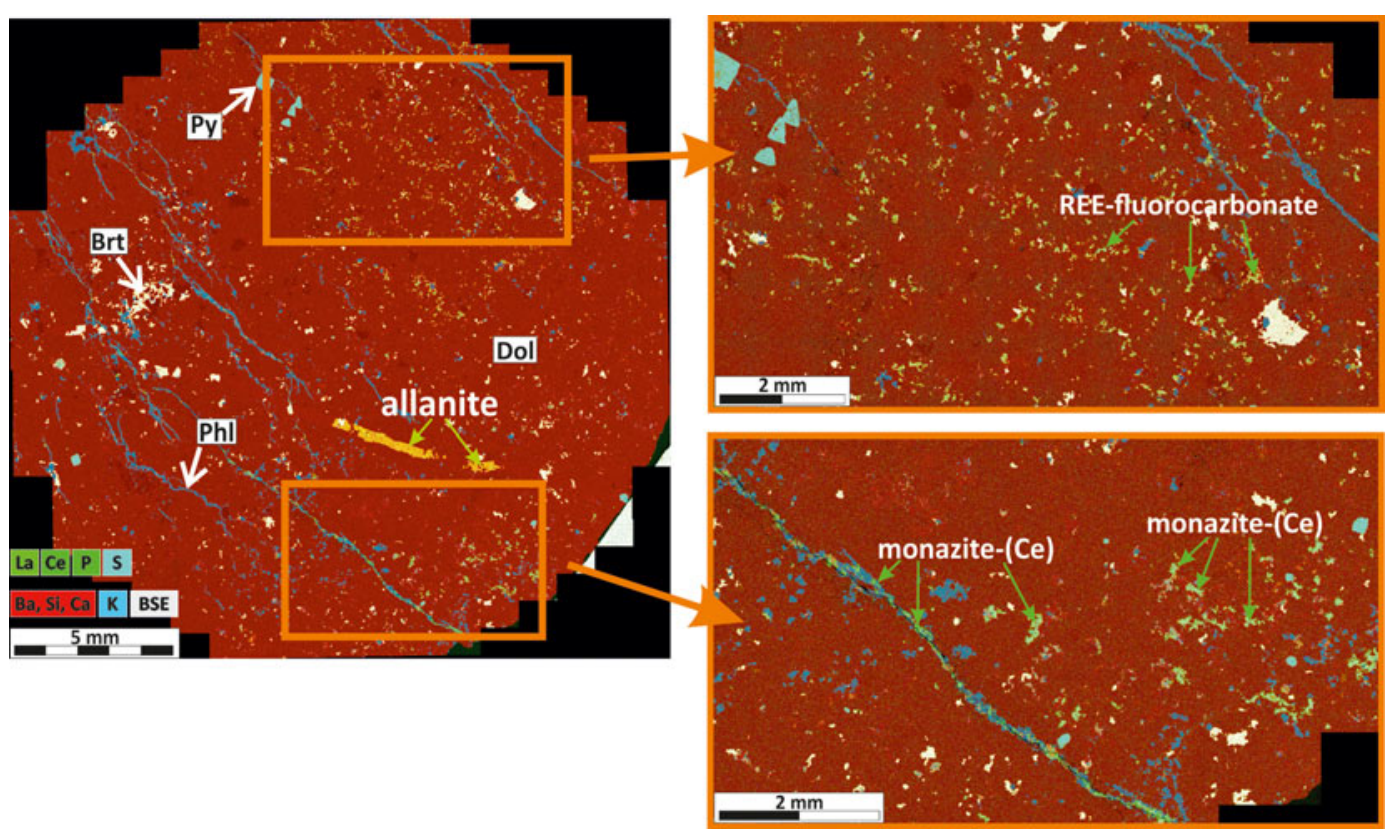

FIG. 3. Large-area chemical map of a transitional rødbergite (sample15-93-FE) with clearly recognizable micro-veins. $R E E$ fluorocarbonates (yellowish) are randomly distributed in the upper part of the polished block. Monazite-(Ce) (green) can be observed in vein set II and in the matrix proximal to vein set II. Allanite (yellow) is part of vein set III. Image obtained by merging $>200$ EDS maps acquired on an SEM. 


\section{MARIEN ETAL.}

show an undulating to en echelon pattern. Irregularly shaped baryte-phlogopite patches $(0.2-2 \mathrm{~mm})$ contain clusters of idiomorphic to hypidiomorphic blade-shaped phlogopite $(100 \mu \mathrm{m})$. Baryte is generally associated with phlogopite but can incorporate relicts of a hematized dolomite-calcite matrix or have a hematite rim. Both phlogopite and baryte are unaltered and show little or no inclusion of hematite. The energy-dispersive X-ray spectroscopy backscattered electron (EDS-BSE) elemental maps reveal a mild halo of higher $\mathrm{Ca}$ concentrations in matrix carbonates in the vicinity of baryte-phlogopite veins (set II).

\section{Apatite-rich inclusions (relics)}

Some rødbergite samples display prominent rounded elliptical inclusions $(\varnothing \sim 5-10 \mathrm{~mm})$ surrounded by the fine, red irregular carbonate matrix of rødbergite. These inclusions are dominated by apatite and dolomite with minor amounts of baryte, hematite, phlogopite and monazite-(Ce) (Fig. 4). Apatite is an early liquidus phase in carbonatite magma, and apatite-rich layers, frequently disrupted by magmatic and post-magmatic processes, are common in carbonatites and are generally interpreted as cumulates (Hornig-Kjarsgaard, 1998; Ihlen et al., 2014; Chakhmouradian et al., 2017). Andersen (1987a) and Schilling (2013) also described apatite cumulate inclusions in calcite carbonatite of the Fen Complex. Our observations show that similar apatite inclusions were present in the carbonatite in Bjørndalen and survived the later rødbergitization event as apatiterich relics. The central part of the apatite relics consist of a primary polycrystalline apatite aggregate with dendritic patches of dolomite, baryte and phlogopite. The apatite relics are partly replaced and the amounts of secondary baryte, phlogopite and dolomite increase towards the rim. The rim itself is completely replaced by secondary minerals and displays a strong concentration of secondary monazite-(Ce) with up to $\sim 20 \%$ of the outer $500 \mu \mathrm{m}$ layer. The formation of monazite at the expense of apatite is a common process caused by the interaction of carbonatite with hydrothermal fluids (Chakhmouradian and Mitchell, 1998; Moore et al., 2015; Giebel et al., 2017). Monazite-(Ce) is often found as an intergrowth with baryte or as polycrystalline elongated aggregates with sizes up to $1 \mathrm{~mm}$. In the vicinity of monazite-(Ce) a higher concentration of calcite is detectable in the carbonate matrix. Monazite-(Ce) is the major REE mineral in the rødbergite and is mainly distributed around the apatite relics and intergrown with baryte in monazite veins (set II) and the rødbergite matrix.

\section{Primary and secondary mineral assemblage}

There is clear textural evidence that the primary minerals of the igneous carbonatite are systematically replaced by a secondary mineral assemblage (Table 2), and this mineralogical change is associated with a systematic variation of REE concentrations in the geochemical profile along the Bjørndalen transect (Fig. 5). Carbonatites of the Bjørndalen transect consist mainly of coarse primary calcite, dolomite, apatite, magnetite, pyrite and columbite. The dominant $R E E$ carriers in these carbonatites are $R E E$ fluorocarbonates (e.g. synchysite-(Ce)/ bastnäsite-(Ce)). Initial alteration of primary carbonatite can be recognized by the development of a fine network of hematite veins along carbonate grain boundaries. As the proportion of fine disseminated hematite between grain boundaries increases, it produces a stronger red colouration in the rock, hence the name rødbergite. The alteration therefore consists of oxidation (of magnetite and pyrite to hematite), recrystallization and replacement of primary minerals, leading to a secondary mineral assemblage of Fe-dolomite, baryte, phlogopite and hematite and accessory calcite, monazite-(Ce), quartz and Ba-bearing feldspar.

$R E E$ fluorocarbonates are partially or completely replaced during alteration. The main $R E E$ carrier in rødbergite is monazite-(Ce) and minor allanite. Allanite is found exclusively as part of allanite vein set III in transitional rødbergite. Monazite-(Ce) can be found in monazite vein set II and in the matrix close to monazite veins. The zone of transitional rødbergite with the highest concentration of $R E E$ also has the highest density of veining. The fully transformed rødbergite has a much lower density of veins and there is an analogy with replacement skarn deposits where the margins of replacements are characterized by vein skarn (feeder fractures), whereas massive skarn shows no clear vein assemblage (Kim et al., 2015). Monazite-(Ce) in rødbergite is mainly distributed around the rims of apatite-rich relics and to a lesser extent in monazite veins.

The main host minerals for Th are monazite-(Ce), thorite and REE fluorocarbonates. The Th concentration in monazite-(Ce) found in the monazite veins in the transitional rødbergite is mainly below the detection limit of the EDS SEM ( $<0.5$ wt.\%).

\section{Geochemical results}

The Bjørndalen transect in the Fen complex provides a complete record of the gradual transformation from igneous carbonatite to rødbergite (Fig. 5). The 

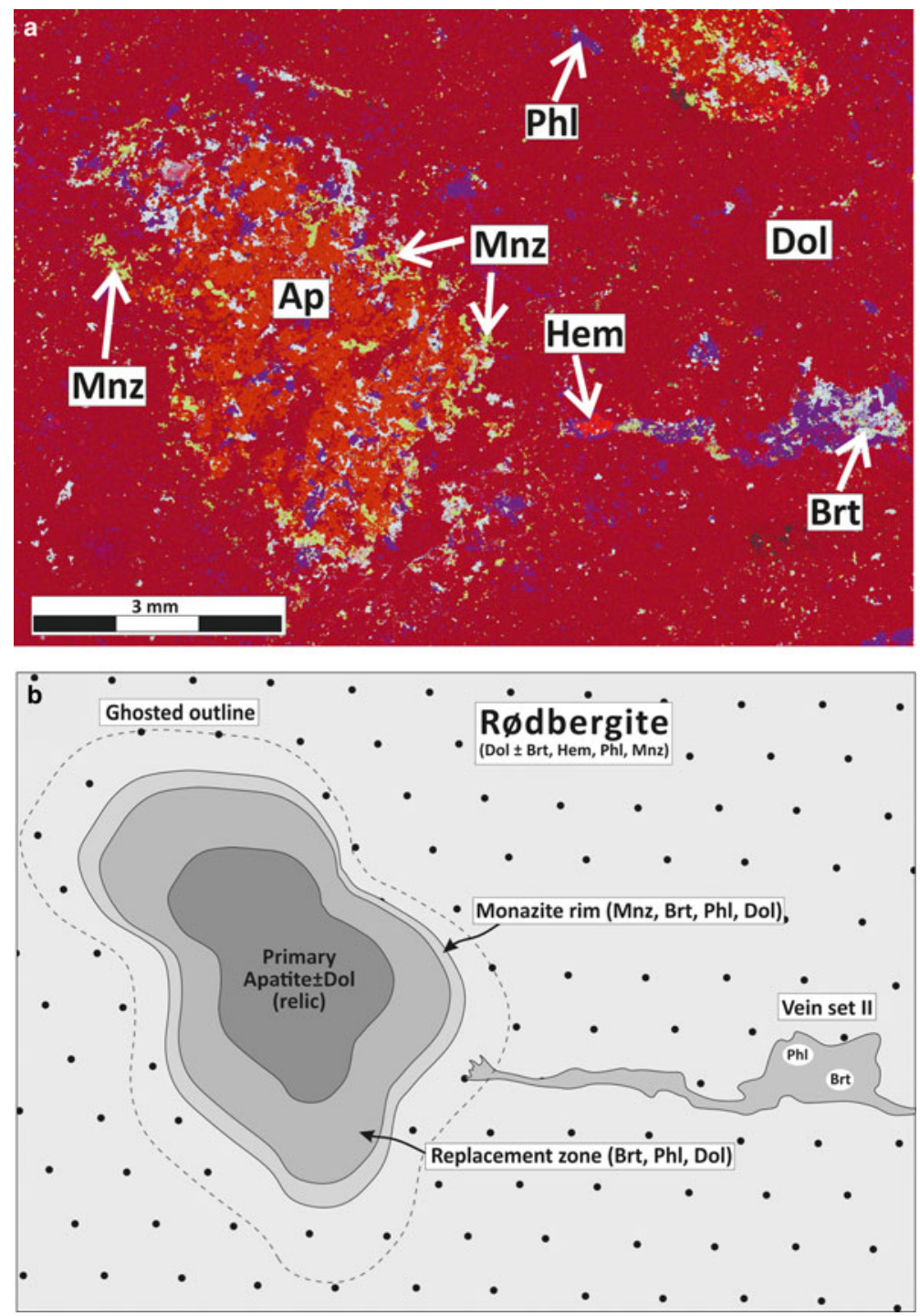

FIG. 4. Large-area chemical map $(a)$ and line drawing $(b)$ of an 'apatite trap' for REE mineralization in rødbergite (sample 15-90-FE). (a) Large area chemical EDS-SEM map of a rødbergite illustrates the distribution of monazite-(Ce) (green-yellow) on the outer rim of a relic of a primary apatite-inclusion-bearing carbonatite, partly replaced during rødbergitization. A rootless baryte-phlogopite vein (set II) - a possible feeder fracture - can be seen to the right of the apatite relic. Mineral abbreviations: Ap - apatite, $\mathrm{Phl}$ - phlogopite, Brt - baryte, Hem - hematite, Mnz - monazite-(Ce). (b) Schematic diagram showing the replacement of the apatite relic. Transport of the replacement fluid occurred along set II veins, which are comprised of baryte, phlogopite \pm hematite and monazite-(Ce). The ghost outline can be seen by the concentration of replacement minerals, e.g. monazite-(Ce). The outer rim of the apatite relic is significantly enriched in monazite-(Ce) plus baryte, phlogopite and dolomite. The replacement zone is a mix of primary apatite and secondary minerals like baryte and phlogopite. The core of the apatite relic consists mainly of primary apatite and dolomite.

progressive alteration is clearly visible at outcrop scale due to a change in colour (reddening) and texture (grain size reduction) of the rock. This change in colour and texture is associated with a systematic change in mineral composition and elemental concentration of the altered carbonatite (Table 2). 


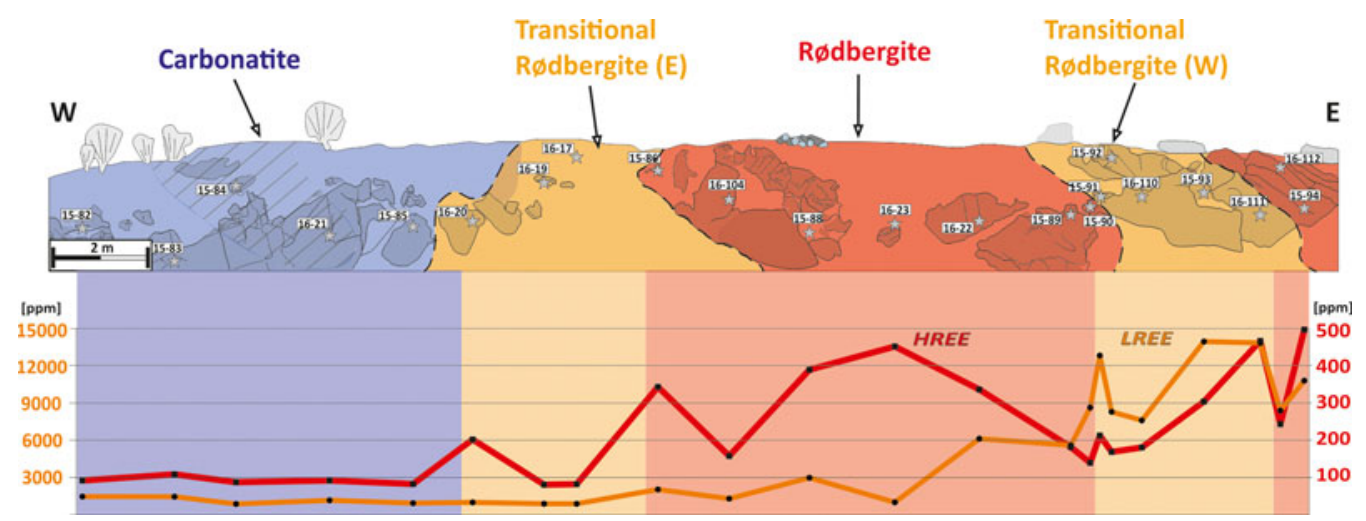

FIG. 5. Sketch of the Bjørndalen transect, which is divided into three different alteration zones. Rødbergite (strong alteration) is found in the centre and western end of the transect and is marked by a red coloration. Transitional rødbergite (mild alteration) is shown in orange and surrounds the central rødbergite. Primary or very weakly altered carbonatite at the western end is marked in blue. The most primary-looking samples were taken from the hatched area. Rocks that outcrop are shaded slightly. The primary carbonatite and the eastern transitional rødbergite are showing low concentrations of HREE and LREE. High values for HREE are in the rødbergite area, and LREE is heavily enriched in the western transitional rødbergite.

The primary igneous carbonatites have the lowest concentrations of REE ( $\leq 1600 \mathrm{ppm}$ TREE) and $\mathrm{Th}(\leq 220 \mathrm{ppm})$ within the Bjørndalen transect (Fig. 5). Samples from the transitional rødbergites show a relatively large variation in REE concentrations. The western transitional rødbergites are only slightly enriched in REE compared to unaltered carbonatite, whereas the eastern transitional rødbergites contain the highest concentration of $R E E$ for the whole Bjørndalen transect $(\leq 16,000 \mathrm{ppm}$ TREE). Although the western and eastern transitional rødbergites appear to be very similar, the eastern transitional rødbergites shows a high density of micro-veins (set I-III). Fully transformed rødbergite is significantly enriched in REE (1200-11,000 TREE) and has the highest concentration of $\mathrm{Th}$ within the transect $(\leq 1000 \mathrm{ppm})$. All of the samples are LREEdominated and show high $\mathrm{La} / \mathrm{Yb}$ ratios relative to chondritic ratios (Fig. 6). The ratio of $\mathrm{La} / \mathrm{Yb}$ differs throughout the transect and is generally higher in the eastern transitional rødbergite (Fig. $6 d$ ), compared to the rødbergite (Fig. 6c) and the western transitional rødbergite (Fig. 6b). High values of La/ $\mathrm{Yb}$ correspond to the overall amount of monazite(Ce). Monazite separates LREE and HREE much more efficiently than apatite or calcite and therefore causes higher $\mathrm{La} / \mathrm{Yb}$ ratios (Chakhmouradian et al., 2016). The highest HREE concentrations are found in rødbergites (up to $650 \mathrm{ppm}$ total HREE) with La/ $\mathrm{Yb}$ ratios extending to very low values $(<20$, but as low as 3 for sample 16-23). The elemental distribution in the Bjørndalen transect produces a zonation with $\mathrm{Th}$ and HREE concentrated in rødbergite at the centre of alteration zone, and LREE locally concentrated in transitional rødbergite with a high vein density.

\section{Discussion}

The progressive alteration from carbonatite to rødbergite along the Bjørndalen transect is associated with a significant enrichment of REE in the altered samples relative to the primary igneous carbonatite. Mineralogical analysis for the present study has shown that the main cause of this enrichment is the precipitation of secondary monazite-(Ce) and the occurrence of monazite and allanite veins, all associated with the rødbergite-forming process.

\section{Primary carbonatite}

Carbonatites are significantly more susceptible to changes in their primary magmatic texture than silicate rocks and their evolution commonly involves a variety of post-magmatic processes, including exsolution and subsolidus re-equilibration with carbothermal-derived fluids (Chakhmouradian et al., 2015; Broom-Fendley et al., 2016). Because the focus of this paper is the rødbergitization, the 

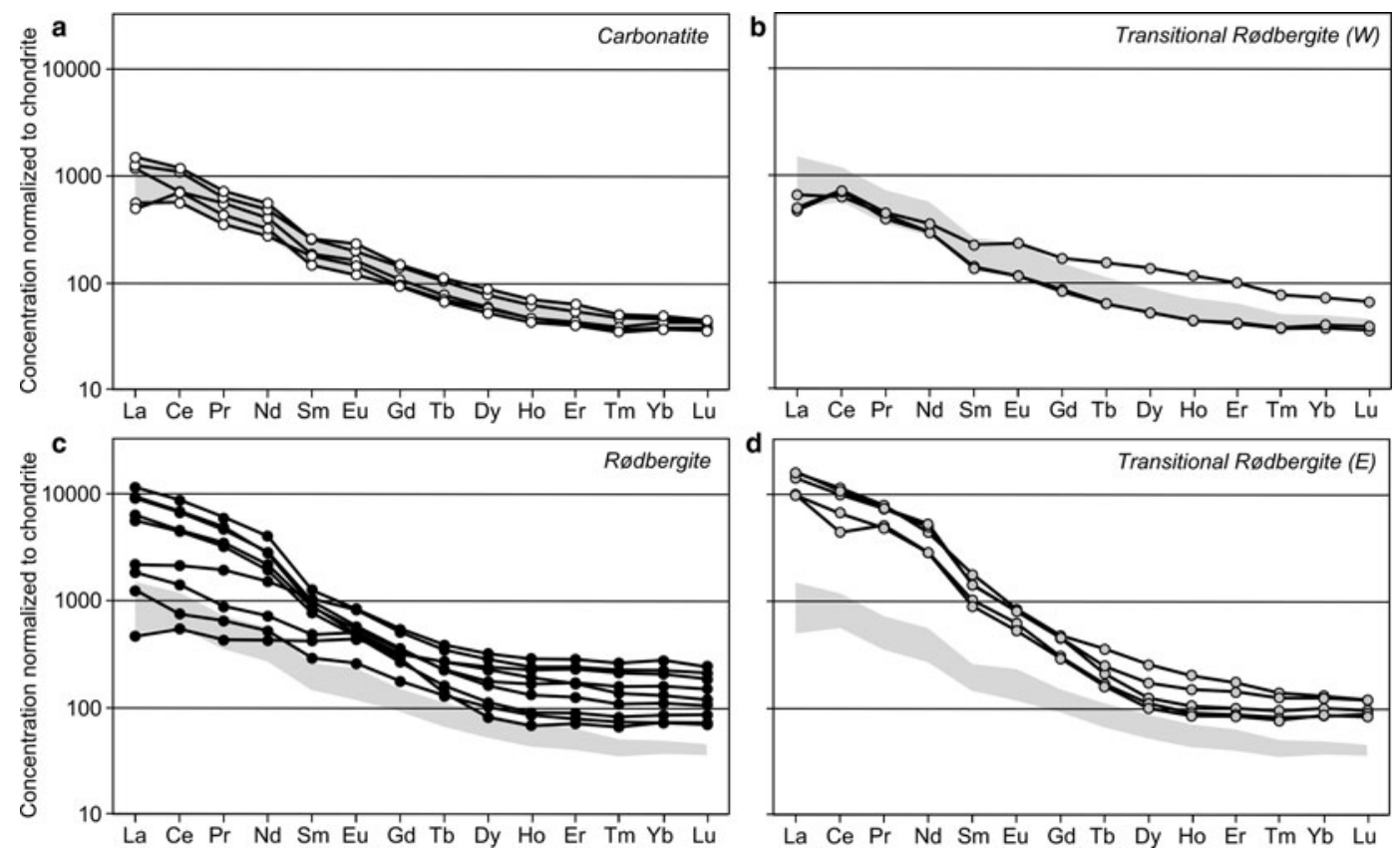

FIG. 6. REE concentrations determined by ICP-MS for Bjørndalen samples normalized to CI1-chondrite values from McDonough and Sun (1995). (a) Igneous carbonatites show a relative enrichment of LREE to HREE with a moderately decreasing slope towards HREE. (b) The western zone of transitional rødbergite has a similar REE distribution to the primary igneous carbonatites, with one sample showing HREE enrichment; (c) The eastern veined transitional rødbergites are distinctly different with high concentrations of $L R E E$ and a steep, slightly irregular slope of the REE graph. $(d)$ Rødbergite samples show a range of REE patterns with some samples having a flat HREE slope and relatively high HREE concentrations not accompanied by large LREE enrichments compared to primary carbonatites. Other rødbergite samples show a strong $L R E E$ enrichment similar to the eastern veined transitional rødbergites, but with generally higher concentrations of HREE. The field defined by REE concentrations in primary carbonatites is shown in light grey.

term 'primary carbonatite' used here includes rocks affected by early post-magmatic processes prior to the rødbergitization. The fine-grained intergrowth of calcite and dolomite in the matrix of primary carbonatite samples from the Bjørndalen transect is almost certainly, in part, the product of postmagmatic dolomitization. According to Chakhmouradian et al. (2016) dolomite has a much smaller capacity to build in REE than calcite (up to $2000 \mathrm{ppm} R E E$ ). During the dolomitization, the excess $R E E$ will be released, which could have been an initial $R E E$ source forming the accessory $R E E$ fluorocarbonates in the primary carbonatite.

As argued by Andersen (1989) and this study, the hydrothermal event causing the formation of rødbergite involves an intense reaction of carbonatite with an oxidizing, at least partly external fluid. The formation of rødbergite discussed here therefore goes well beyond the classical early post-magmatic processes of exsolution and subsolidus re-equilibration in carbonatites. The formation of the major minerals e.g. calcite, dolomite, apatite and pyrite happened before the rødbergitization. On the other hand, there is textural evidence that the accessory minerals in the primary carbonatite listed in Table 2 are in part secondary in nature. Based on the available evidence this could be the result of post-magmatic processes or the remote alteration halo of the rødbergitization.

\section{Secondary nature of monazite-(Ce)}

Monazite-(Ce), the dominant REE mineral in rødbergite and transitional rødbergite, is paragenetically related to the secondary assemblage of hematite, baryte and phlogopite, and closely spatially associated with primary apatite-dolomite relics. The concentration of secondary monazite-(Ce) in the 


\section{MARIEN ETAL.}

outer rim of primary apatite-dolomite relics in rødbergite and transitional rødbergite can be explained as a replacement reaction. While the alteration fluid was penetrating the carbonatite through grain boundaries and veins, hematite, baryte, phlogopite and carbonates were precipitated together with minor monazite-(Ce). When the hydrothermal fluid interacted with apatite, $R E E$ preferentially precipitated the $R E E$ phosphate monazite-(Ce), by either partial or full replacement of apatite. This observation can also be made for smaller apatite crystals, which are completely pseudomorphed by monazite-(Ce) (Fig. $2 f$ ). Hence apatite, in particular the apatite-rich relics, acted as a $R E E$ 'trap' during the formation of rødbergite.

\section{REE stability in hydrothermal fluids in the Fen Complex}

The evidence for breakdown of REE fluorocarbonates in igneous carbonatites and the strong enrichment of $R E E$ in rødbergites - by formation of secondary $R E E$ minerals in the matrix, in veins and around apatite 'traps' - are evidence for solubility and mobility of $R E E$ in the fluids that caused the 'rødbergitization'. Several experimental studies have emphasized the important role of fluoride, sulfate and chloride ligands to form stable $R E E$ complexes in hydrothermal fluids at 200 $400^{\circ} \mathrm{C}$ in geological environments (Williams-Jones et al., 2012; Williams-Jones and Migdisov, 2014), with $R E E$ sulfate complexes dominating at temperatures $>300^{\circ} \mathrm{C}$ in weakly acidic fluids (Migdisov and Williams-Jones, 2014). The ubiquitous presence of baryte as part of the secondary assemblage in rødbergite, including in the monazite and allanite veins, suggests an important role for sulfate complexes in the Fen Complex. In addition, experimental studies have shown that sulfate inhibits the formation of monazite from fluorapatite (Harlov and Förster, 2004), which highlights the importance of baryte precipitation coupled with monazite-(Ce) formation (Feng et al., 2016). Sulfate was probably formed by breakdown of primary sulfides in carbonatites when they reacted with an oxidizing hydrothermal fluid.

Experimental studies have further demonstrated that the stabilities of REE fluoride, -sulfate and -chloride complexes decrease strongly with decreasing temperature and increasing $\mathrm{pH}$ (Williams-Jones et al., 2012; Migdisov and Williams-Jones, 2014; Williams-Jones and Migdisov, 2014). Therefore, cooling of the hydrothermal fluid, or reaction with carbonate host rocks leading to a $\mathrm{pH}$-increase in the fluid, are in general suitable geological mechanisms triggering precipitation of $R E E$ minerals from aqueous solutions. Of particular relevance to the Fen Complex is the experimental evidence that fluid-rock reactions of fluorine- and sulfate-bearing aqueous fluids with phosphate-rich host rock is a highly effective trigger for the destabilization of the aqueous $R E E$ complexes, resulting in the precipitation of REE phosphate minerals such as monazite(Ce) (Migdisov and Williams-Jones, 2014; Louvel et al., 2015). This mechanism fully explains the textural evidence that relics of cumulate apatite layers acted as a trap for REE via the crystallization of monazite-(Ce) in rødbergite in the Fen Complex.

\section{Evidence for lanthanide tetrad effects?}

The chondrite-normalized REE patterns differ from smooth continuous curves and display steps and rounded segments for blocks of REE (Fig. 6; see also supplementary Fig. S1, details below.). These patterns cannot simply be explained by the different ionic radii of the $R E E$ and are generally referred to as the 'tetrad-effect' of the lanthanides, where the chondrite-normalized distributions are split into four concave or convex segments (La-Nd, (Pm)-Gd, GdHo and Er-Lu) called tetrads (Monecke et al., 2002). The origin of the lanthanide tetrad effect is the subject of ongoing discussions, and the effect is not commonly observed in geological materials, with the exception of evolved granites with a hightemperature hydrothermal component (Irber, 1999; Monecke et al., 2002). Recent results suggest that the tetrad effect in highly evolved granites can be caused by the fractionation of monazite and xenotime (Duc-Tin and Keppler, 2015). Our initial results suggest that there are concave patterns for the first tetrad (La-Ce-Pr-Nd) in carbonatites and rødbergites, and convex patterns for the $2^{\text {nd }}((\mathrm{Pm})-$ $\mathrm{Sm}-\mathrm{Eu}-\mathrm{Gd})$ and $3^{\text {rd }}$ tetrad (Gd-Tb-Dy-Ho) in transitional and fully altered rødbergites (supplementary Fig. S1), but this is the subject of ongoing work.

\section{LREE and HREE decoupling}

The geochemical results assembled here also show clear evidence for a decoupling of $L R E E$ and HREE during the formation of rødbergite, and monazite-(Ce) and allanite veins interpreted as feeder fractures very highly enriched in LREE. Experimental work has shown that at temperatures 
of $>150^{\circ} \mathrm{C}$ aqueous $L R E E$ complexes are generally more stable than HREE complexes, in particular those involving fluoride as the ligand (WilliamsJones et al., 2012). In geological terms, this means that HREE drop out of solution first when aqueous REE complexes are destabilized, and that LREE remain in solution longer and are transported over longer distances compared to HREE. For instance, Williams-Jones et al. (2012) showed how a temperature drop of a $R E E$-bearing fluid in a feeder vein system resulted in a distinct fractionation of $R E E$, with the $L R E E$ being transported further along the feeder veins, down the temperature gradient.

Therefore, the observed LREE-HREE decoupling and the concentration of HREE in the central rødbergite in the Fen Complex can be explained by their relative immobility compared to LREE. HREE are precipitated in the area of strongest alteration (rødbergite), whereas LREE remained in solution and were transported further away from the centre of alteration domain, into the alteration halo (now represented by the transitional rødbergites). The hydrothermal monazite and allanite micro-veins are an inherent part of the rødbergite formation process, and where these veins (possible feeder fractures) are abundant, as in the eastern transitional rødbergite zone, there is the strongest enrichment of $L R E E$ in the bulk-rock samples.

\section{Th enrichment during rødbergitization}

Thorium is enriched in rødbergite along the Bjørndalen transect in a similar pattern to REE. HREE and Th are most enriched in rødbergite (relative to transitional rødbergite and carbonatite (Table 1). Secondary Th minerals (thorite) and secondary Th-bearing minerals such as monazite(Ce) are associated with the rødbergitization. Samples that show a significant $L R E E$ concentration due to a high density of $R E E$ mineral bearing veins do not show elevated Th concentrations. Therefore Th was probably less mobile than $L R E E$ and precipitated earlier, together with the HREE, in the centre of the alteration domain.

\section{Nature of the hydrothermal fluids in the Fen Complex}

A comparison between the primary and secondary assemblages described here suggests that the hydrothermal fluids involved in the formation of rødbergite and in the observed REE enrichment were more oxidized than the primary magnetite- pyrite-bearing carbonatites; this oxidized character must have been acquired outside of the Fen Complex. Furthermore, Andersen (1984) presented strontium and oxygen isotopic evidence to show that fluids involved in rødbergite formation had high ${ }^{87} \mathrm{Sr} /{ }^{86} \mathrm{Sr}$ ratios and elevated $\partial^{18} \mathrm{O}$. This suggests that the fluids involved in the REE mineralization in the Fen Complex were not simply evolved melt-like hydrous fluids; such late-magmatic fluids often play a critical role in producing high grades in REE resources (Wall and Mariano, 1996; Duraiswami and Shaikh, 2014; Smith et al., 2016; Bodeving et al., 2017). Instead, the rødbergite fluids were hydrothermal and had at least partly equilibrated with Precambrian quartzofeldspathic gneisses outside of the Fen Complex, and possibly with groundwater (Andersen, 1984). It has been well documented that $R E E$ can be highly mobile in such fluids, producing $R E E$ mineralization well outside of their magmatic source rock. This has been shown for carbonatites, e.g. Kangankunde (Wall and Mariano, 1996), as well as for peralkaline complexes, e.g. Strange Lake (Gysi and Williams-Jones, 2013). Sediment-hosted replacement-type carbonatite REE deposits, e.g. Bayan Obo (Campbell and Henderson, 1997; Wu, 2008; Smith et al., 2015), breccia-hosted $\mathrm{Fe}-\mathrm{Cu}-$ Au-REE deposits, e.g. Olympic Dam (Oreskes and Einaudi, 1990; Groves and Vielreicher, 2001; McPhie et al., 2011), and unconformity-type $R E E \pm \mathrm{U}$ deposits, e.g. Athabasca Basin (Fayek and Kyser, 1997) are examples of even more distal deposits for which a link with fluids sourced by igneous carbonatite at depth have been proposed. The REE mineralization of Mount Weld, in particular, shows similar processes with an horizon of secondary monazite within carbonatite laterite produced by groundwater alteration of apatite (Lottermoser, 1990; Smith et al., 2016).

\section{A model for rødbergite formation}

The present findings are not fully consistent with the existing model of Andersen $(1984,1986)$ for the $R E E$ mineralization in rødbergite of the Fen Complex. A key element of the existing model involves a progressive residual enrichment of insoluble REE minerals by leaching and removal of the carbonate minerals during hydrothermal alteration (Andersen, 1984). Both Andersen's model and our model proposed here involve postmagmatic oxidizing hydrothermal fluids which equilibrated with rocks outside of the Fen 


\section{MARIEN ETAL.}

Complex. The present authors believe, however, that the REE concentration cannot be explained solely by a residual enrichment of primary $R E E$ minerals for the following reasons: (1) The main $R E E$ carrier mineral changes from REE fluorocarbonate in the carbonatite, to monazite- $(\mathrm{Ce})$ in the rødbergite, and this change must have involved the dissolution and reprecipitation of REE. Textural evidence has been presented here for the progressive breakdown and dissolution (leaching) of primary $R E E$ fluorocarbonates from the primary igneous carbonatites by a hydrothermal fluid. (2) The monazite-(Ce) in the rødbergite is predominantly found in a network of fine veins and is highly enriched where these veins are in contact or closely associated with primary apatite-dolomite relics as a result of the replacement of apatite by monazite(Ce), with the apatite relics acting as a REE trap. These textures require $R E E$ to be transported in a fluid phase, and they have not been observed in primary carbonatite. (3) REE enrichment by more than an order of magnitude from carbonatite to rødbergite is observed in the Bjørndalen transect. This would require a major volume reduction by $90 \%$ and would be predicted to be accompanied by formation of porous rocks with cavernous mineral assemblages (Chakhmouradian et al., 2015), as well as collapse breccias. No field evidence for extensive brecciation (Andersen, 1987a), or formation of highly porous, vug-rich rocks is apparent in the Bjørndalen transect.

We propose a general model for the formation of rødbergite in the studied transect at Bjørndalen that is consistent with our findings and that can also be applied to the Fen Complex as a whole. Our model involves leaching of primary $R E E$ fluorocarbonates from igneous carbonatites by highly oxidizing, fluorine and sulfate-rich fluids, and transport, reprecipitation and concentration of REE in monazite-(Ce) in zones of extensive fluid-rock interaction now marked by rødbergitic rocks, surrounded by alteration halos. The progressive alteration of carbonatite to rødbergite in the Bjørndalen transect by an oxidizing hydrothermal fluid caused the breakdown of primary $R E E$ fluorocarbonates and precipitation of secondary monazite-(Ce) in rødbergite. This secondary monazite- $(\mathrm{Ce})$ is concentrated along a fine irregular network of veins and around primary apatitedolomite relics, where monazite-(Ce) is replacing apatite. The secondary monazite-(Ce) together with multiple generations of monazite- and allanitebearing veins can account for the $R E E$ enrichment in rødbergite and transitional rødbergite samples by an order of magnitude more than the primary carbonatite. The relative enrichments of HREE, $L R E E$ and Th are variable throughout the Bjørndalen transect due to different element mobilities and the density of the $R E E$ vein networks, which cause the development of overlapping zones of enrichment, with Th and HREE-rich zones being closer to the centre of alteration than the LREE-rich zone found in the alteration halo.

The above model for REE mineralization in the rødbergite has significant implications for a $R E E$ exploration strategy. The model predicts the existence of separate zones of HREE, LREE and Th enrichment throughout the Fen Complex. The selective exploitation of HREE and LREE without high Th concentrations (generally considered an undesirable element in $R E E$ exploitation) can now be assessed better. Moreover, LREE might form an enriched halo further away from the centre of alteration than expected. Because the REE mineralization was not formed by passive enrichment of primary $R E E$ minerals, the alteration fluid must have contained REE. Therefore, any rock in the complex (e.g. damtjernite or fenite) that came into contact with the same rødbergite-forming fluid may be a potential exploration target.

\section{Conclusions}

The detailed mineralogical and geochemical investigations of the progressive transformation of primary carbonatite to rødbergite has provided new insights into the REE concentration processes during the alteration of carbonatite: (1) The progressive alteration is associated with a 10 -fold enrichment of $R E E$ in the altered samples relative to the primary igneous carbonatite. The main cause of this enrichment is the precipitation of secondary monazite-(Ce) in the matrix, and the occurrence of monazite and allanite micro-veins, all associated with the rødbergiteforming process. (2) The breakdown of primary $R E E$ fluorocarbonates in carbonatites and the formation of monazite-bearing rødbergite is caused by interaction between carbonatite and an oxidizing aqueous hydrothermal fluid, in which $R E E$ were mobile. (3) We found that secondary monazite-(Ce) is concentrated around apatite-rich relics in rødbergite. These apatite-rich relics acted as a trap for REE by triggering the precipitation of secondary monazite(Ce), a mechanism predicted by physical-chemical experiments. (4) In addition to the enrichment of $R E E$, the formation of rødbergite is also associated with an increased concentration of Th. Evidence was 
found in the present study, however, for partial decoupling of LREE, HREE and Th in the Bjørndalen transect, and there are separate zones of LREE, HREE and Th enrichment.

Building on the model for rødbergite formation by Andersen (1984), the new model for the formation of rødbergite can explain all the reported features and has a significant implication for a future $R E E$ exploration strategy. The model predicts the existence of separate zones of $L R E E, H R E E$ and Th enrichment throughout the Fen Complex and highlights the importance of apatite-rich relics and $R E E$ mineral veining for high-grade $R E E$ ore.

\section{Acknowledgements}

The authors acknowledge the support of Drs Natasha Stephen (Plymouth Electron Microscopy Centre) and Rob Clough (Plymouth ICP-MS lab). They are also grateful for the support provided by Fen Minerals AS in Norway. Astrid Marien is thanked for her constructive review of the earlier draft of this paper, and Alex Dawson for his valuable help on the figures. Furthermore, the authors want to thank Dr Jindrich Kynicky and an anonymous reviewer for their constructive comments on this manuscript.

\section{Supplementary material}

To view supplementary material for this article, please visit https://doi.org/10.1180/minmag.2017.081.070

\section{References}

21 st North (2014) The Fen Rare Earth Element Deposit. Ulefoss, South Norway.

Andersen, T. (1984) Secondary processes in carbonatites: petrology of "rødberg" (hematite-calcite-dolomite carbonatite) in the Fen central complex, Telemark (South Norway). Lithos, 17, 227-245.

Andersen, T. (1986) Magmatic fluids in the Fen carbonatite complex, S.E. Norway. Contributions to Mineralogy and Petrology, 93, 491-503.

Andersen, T. (1987a) Mantle and crustal components in a carbonatite complex, and the evolution of carbonatite magma: REE and isotopic evidence from the Fen complex, southeast Norway. Chemical Geology: Isotope Geoscience section, 65, 147-166.

Andersen, T. (1987b) A model for the evolution of hematite carbonatite, based on whole-rock major and trace element data from the Fen complex, southeast Norway. Applied Geochemistry, 2, 163-180.

Andersen, T. (1989) A model for the evolution of hematite carbonatite, based on whole-rock major and trace element data from the Fen complex, southeast Norway. Mineralogical Magazine, 53, 20.

Bergstøl, S. and Svinndal, S. (1960) The carbonatite and per-alkaline rocks of the Fen area. Norges geologiske undersøkelse, Vol. 208, p. 99-110.

Bodeving, S., Williams-Jones, A.E. and Swinden, S. (2017) Carbonate-silicate melt immiscibility, REE mineralising fluids, and the evolution of the Lofdal Intrusive Suite, Namibia. Lithos, 268-271, 383-398.

Bokhari, S.N.H. and Meisel, T.C. (2016) Method Development and Optimisation of Sodium Peroxide Sintering for Geological Samples. Geostandards and Geoanalytical Research.

Brøgger, W.C. (1921) Die Eruptivgesteine des Kristianiagebietes, IV. Das Fengebiet in Telemark, Norwegen, $494 \mathrm{pp}$.

Broom-Fendley, S., Styles, M.T., Appleton, J.D., Gunn, G. and Wall, F. (2016) Evidence for dissolutionreprecipitation of apatite and preferential LREE mobility in carbonatite-derived late-stage hydrothermal processes. American Mineralogist, 101, 596-611.

Campbell, L.S. and Henderson, P. (1997) Apatite paragenesis in the Bayan Obo REE-Nb-Fe ore deposit, Inner Mongolia, China. Lithos, 42, 89-103.

Chakhmouradian, A.R. and Mitchell, R.H. (1998) Lueshite, pyrochlore and monazite-(Ce) from apatite-dolomite carbonatite, Lesnaya Varaka complex, Kola Peninsula, Russia. Mineralogical Magazine, 62, 769-782.

Chakhmouradian, A.R., Reguir, E.P. and Zaitsev, A.N. (2015) Calcite and dolomite in intrusive carbonatites. I. Textural variations. Mineralogy and Petrology, 110, 333-360.

Chakhmouradian, A.R., Reguir, E.P., Couëslan, C. and Yang, P. (2016) Calcite and dolomite in intrusive carbonatites. II. Trace-element variations. Mineralogy and Petrology, 110, 361-377.

Chakhmouradian, A.R., Reguir, E.P., Zaitsev, A.N., Couëslan, C., Xu, C., Kynický, J., Mumin, A.H. and Yang, P. (2017) Apatite in carbonatitic rocks: Compositional variation, zoning, element partitioning and petrogenetic significance. Lithos, 274-275, 188-213.

Cordeiro, P.F.d.O., Brod, J.A., Palmieri, M., de Oliveira, C.G., Barbosa, E.S.R., Santos, R.V., Gaspar, J.C. and Assis, L.C. (2011) The Catalão I niobium deposit, central Brazil: Resources, geology and pyrochlore chemistry. Ore Geology Reviews, 41, 112-121.

Cullers, R.L. and Graf, J.L. (1984) Rare earth elements in igneous rocks of the continental crust: predominantly basic and ultrbasic rocks. Pp. 237-274 in: Developments in Geochemistry, Vol. 2: Rare Earth Element Geochemistry (P. Henderson, editor). Elsevier, Amsterdam.

Duc-Tin, Q. and Keppler, H. (2015) Monazite and xenotime solubility in granitic melts and the origin of the lanthanide tetrad effect. Contributions to 


\section{MARIEN ETAL.}

Mineralogy and Petrology, 169, 8, https://doi.org/10. 1007/s00410-014-1100-9.

Duraiswami, R. and Shaikh, T. (2014) Fluid-rock interaction in the Kangankunde Carbonatite Complex, Malawi: SEM based evidence for late stage pervasive hydrothermal mineralisation. Central European Journal of Geology, 6, 476-491.

European Commission (2014) Report on Critical Raw Materials for the EU. Report of the Ad-hoc Working Group on Defining Critical Raw Materials, 41 pp.

Fayek, M. and Kyser, T.K. (1997) Characterization of multiple fluid-flow events and rare-earth-element mobility associated with formation of unconformitytype uranium deposits in the Athabasca Basin, Saskatchewan. The Canadian Mineralogist, 35, 627-658.

Feng, M., Xu, C., Kynicky, J., Zeng, L. and Song, W. (2016) Rare earth element enrichment in Palaeoproterozoic Fengzhen carbonatite from the North China block. International Geology Review, 58, 1940-1950.

Giebel, R.J., Gauert, C.D.K., Marks, M.A.W., Costin, G. and Markl, G. (2017) Multi-stage formation of REE minerals in the Palabora Carbonatite Complex, South Africa. American Mineralogist, 102, 1218-1233.

Griffin, W.L. and Taylor, P.N. (1975) The Fen Damkjernite: Petrology of a "central-complex kimberlite". Physics and Chemistry of the Earth, 9, $163-177$.

Groves, D.I. and Vielreicher, N.M. (2001) The Phalabowra (Palabora) carbonatite-hosted magnetitecopper sulfide deposit, South Africa: an end-member of the iron-oxide copper-gold-rare earth element deposit group? Mineralium Deposita, 36, 189-194.

Gysi, A.P. and Williams-Jones, A.E. (2013) Hydrothermal mobilization of pegmatite-hosted $\mathrm{REE}$ and $\mathrm{Zr}$ at Strange Lake, Canada: A reaction path model. Geochimica et Cosmochimica Acta, 122, 324-352.

Harlov, D.E. and Förster, H.-J. (2004) Fluid-induced nucleation of $(\mathrm{Y}+\mathrm{REE})$-phosphate minerals within apatite: Nature and experiment. Part II. Fluorapatite. American Mineralogist, 88, 1209-1229.

Henderson, P. (1996) The rare earth elements: introduction and review. Pp. 1-20 in: Rare Earth Minerals, Chemistry, Origin and Ore Deposits (A.P. Jones, F. Wall and C.T. Williams, editors). The Mineralogical Society Series, 7, Chapman \& Hall, London.

Hornig-Kjarsgaard, I. (1998) Rare earth elements in sovitic carbonatites and their mineral phases. Journal of Petrology, 39, 2105-2121.

Ihlen, P.M., Schiellerup, H., Gautneb, H. and Skår, Ø. (2014) Characterization of apatite resources in Norway and their REE potential - A review. Ore Geology Reviews, 58, 126-147.

Irber, W. (1999) The lanthanide tetrad effect and its correlation with $\mathrm{K} / \mathrm{Rb}, \mathrm{Eu} / \mathrm{Eu} *, \mathrm{Sr} / \mathrm{Eu}, \mathrm{Y} / \mathrm{Ho}$, and $\mathrm{Zr}$ /
Hf of evolving peraluminous granite suites. Geochimica et Cosmochimica Acta, 63, 489-508.

Kim, E.-J., Shin, D., Shin, S., Nam, H.-T. and Park, S. (2015) Skarn zonation and rock physical properties of the Wondong $\mathrm{Fe}-\mathrm{Pb}-\mathrm{Zn}$ polymetallic deposit, Korea. Geosciences Journal, 19, 587-598.

Lottermoser, B.G. (1990) Rare-earth element mineralisation within the Mt. Weld carbonatite laterite, Western Australia. Lithos, 24, 151-167.

Louvel, M., Bordage, A., Testemale, D., Zhou, L. and Mavrogenes, J. (2015) Hydrothermal controls on the genesis of REE deposits: Insights from an in situ XAS study of $\mathrm{Yb}$ solubility and speciation in high temperature fluids $\left(\mathrm{T}<400^{\circ} \mathrm{C}\right)$. Chemical Geology, 417, 228-237.

Mariano, A. (1989) Nature of economic mineralization in carbonatites and related rocks. Pp. 27 in: Carbonatites: Genesis and Evolution (D.R. Bell, editor). Unwin Hyman Ltd., London.

Marien, C., Dijkstra, A. and Wilkins, C. (2016) Rødbergite - a potential source for REE within the Fen Complex, Norway. Abstracts, 2nd European Mineralogical Conference, Rimini, Italy.

McDonough, W.F. and Sun, S.-S. (1995) The composition of the Earth. Chemical Geology, 120, 223-253.

McPhie, J., Kamenetsky, V.S., Chambefort, I., Ehrig, K. and Green, N. (2011) Origin of the supergiant Olympic Dam Cu-U-Au-Ag deposit, South Australia: Was a sedimentary basin involved? Geology, 39, 795-798.

Meert, J.G., Torsvik, T.H., Eide, E.A. and Dahlgren, S. (1998) Tectonic significance of the Fen Province, S. Norway: Constraints from geochronology and paleomagnetism. The Journal of Geology, 106, 553-564.

Migdisov, A.A. and Williams-Jones, A.E. (2014) Hydrothermal transport and deposition of the rare earth elements by fluorine-bearing aqueous liquids. Mineralium Deposita, 49, 987-997.

Mitchell, R.H. and Brunfelt, A.O. (1975) Rare earth element geochemistry of the Fen alkaline complex, Norway. Contributions to Mineralogy and Petrology, 52, 247-259.

Monecke, T., Kempe, U., Monecke, J., Sala, M. and Wolf, D. (2002) Tetrad effect in rare earth element distribution patterns: a method of quantification with application to rock and mineral samples from graniterelated rare metal deposits. Geochimica et Cosmochimica Acta, 66, 1185-1196.

Moore, M., Chakhmouradian, A.R., Mariano, A.N. and Sidhu, R. (2015) Evolution of rare-earth mineralization in the Bear Lodge carbonatite, Wyoming: Mineralogical and isotopic evidence. Ore Geology Reviews, 64, 499-521.

Oreskes, N. and Einaudi, M.T. (1990) Origin of rare earth element-enriched hematite breccias at the Olympic Dam Cu-U-Au-Ag deposit, Roxby Downs, South Australia. Economic Geology, 85, 1-28. 
Pirajno, F., González-Álvarez, I., Chen, W., Kyser, K.T., Simonetti, A., Leduc, E. and leGras, M. (2014) The Gifford Creek Ferrocarbonatite Complex, Gascoyne Province, Western Australia: Associated fenitic alteration and a putative link with the $\sim 1075 \mathrm{Ma}$ Warakurna LIP. Lithos, 202-203, $100-119$.

Ramberg, I.B. (1973) Gravity studies of the Fen complex, Norway, and their petrological significance. Contributions to Mineralogy and Petrology, 38, 115-134.

Sæther, E. (1957) The alkaline rock province of the Fen area in southern Norway, 1. Videnskapselsk, Trondheim, $148 \mathrm{pp}$.

Schilling, J. (2013) Petrography, mineralogy and wholerock data of the major litholgies of the Fen Complex. Geological Survey of Norway.

Smith, M.P., Campbell, L.S. and Kynicky, J. (2015) A review of the genesis of the world class Bayan Obo $\mathrm{Fe}-\mathrm{REE}-\mathrm{Nb}$ deposits, Inner Mongolia, China: Multistage processes and outstanding questions. Ore Geology Reviews, 64, 459-476.
Smith, M.P., Moore, K., Kavecsánszki, D., Finch, A.A., Kynicky, J. and Wall, F. (2016) From mantle to critical zone: A review of large and giant sized deposits of the rare earth elements. Geoscience Frontiers, 7, 315-334.

Wall, F. and Mariano, A.N. (1996) Rare earth minerals in carbonatites: a discussion centred on the Kangankunde Carbonatite, Malawi. Pp. 193-226 in: Rare Earth Minerals Chemistry: Origin and Ore Deposits (A.P. Jones, F. Wall and C.T. Williams, Editors). The Mineralogical Society Series, 7, Chapman \& Hall, London.

Williams-Jones, A.E. and Migdisov, A.A. (2014) Rare earth element transport and deposition by hydrothermal fluids. Acta Geologica Sinica - English Edition, 88, 472-474.

Williams-Jones, A.E., Migdisov, A.A. and Samson, I.M. (2012) Hydrothermal mobilisation of the rare earth elements - a Tale of "Ceria" and "Yttria". Elements, 8, $355-360$.

Wu, C. (2008) Bayan Obo controversy: Carbonatites versus iron oxide-Cu-Au-(REE-U). Resource Geology, 58, $348-354$. 